\title{
Microsatellite multiplex assay for the analysis of Atlantic sturgeon populations
}

\author{
H. Panagiotopoulou • D. Popovic • K. Zalewska • \\ P. Weglenski • A. Stankovic
}

Received: 2 September 2013 / Accepted: 7 April 2014 / Published online: 4 May 2014

(C) The Author(s) 2014. This article is published with open access at Springerlink.com

\begin{abstract}
We have developed a multiplex assay covering 16 microsatellite loci, amplified in four polymerase chain reaction (PCR) assays, and loaded on the ABI DNA Analyzer in two separate panels. The assay was tested on 603 individuals originating from wild populations and hatchery stocks of Atlantic sturgeon. The assay was also tested on 12 individuals of European sturgeon and appeared to be almost equally useful. The multiplex assay designed in this study can be successfully applied in studies requiring high genetic resolution, such as relatedness analysis, selective breeding programs, and stock identification of Atlantic sturgeon.
\end{abstract}

Keywords Microsatellite loci · Multiplex PCR · Atlantic sturgeon · European sturgeon

Electronic supplementary material The online version of this article (doi:10.1007/s13353-014-0216-y) contains supplementary material, which is available to authorized users.

H. Panagiotopoulou • P. Weglenski • A. Stankovic

Institute of Biochemistry and Biophysics, Polish Academy

of Sciences, Pawińskiego 5a, 02-106 Warsaw, Poland

D. Popovic $\cdot$ P. Weglenski

Centre of New Technologies (CeNT), University of Warsaw,

ul. Żwirki i Wigury 93, 02-089 Warsaw, Poland

K. Zalewska $\cdot$ A. Stankovic

Faculty of Biology, Institute of Genetics and Biotechnology,

University of Warsaw, Pawińskiego 5a, 02-106 Warsaw, Poland

A. Stankovic

The Antiquity of Southeastern Europe Research Center, University of Warsaw, Krakowskie Przedmieście 32, 00-927 Warsaw, Poland

H. Panagiotopoulou $(\triangle)$

Institute of Genetics and Biotechnology, University of Warsaw,

Pawińskiego 5a, 02-106 Warsaw, Poland

e-mail:hpana@wp.pl

\section{Introduction}

Atlantic (Acipenser oxyrinchus) and European (A. sturio) sturgeons belong to the Acipenseridae, considered one of the most endangered fish families (Pikitch et al. 2005; Ludwig 2006). Historically, Atlantic sturgeon inhabited the East Coast of North America, and Western and Central Europe, including the Baltic Sea, whereas the European sturgeon's habitat was restricted to Western and Southern Europe (Ludwig et al. 2002 and 2009; Stankovic 2011; Chassaing et al. 2011a, 2013). During the last two centuries, the populations of Atlantic and European sturgeons have declined drastically due to river damming, habitat destruction, and overexploitation (Waldman and Wirgin 1998; Vecsei 2005; Ludwig 2006). At present, both species are endangered across the whole of their historical range; in the case of the European sturgeon, only a single population exists, in the Gironde-Garonne-Dordogne watershed (France) (Lassalle et al. 2011). The Atlantic sturgeon became extinct in the wild in Europe in 1996, when the last specimen was captured in the Baltic Sea (Paaver 1999). In Poland, a sturgeon restitution program was launched in 2004 (Kolman et al. 2011). Material from the St. John River has been used to build up broodstock in Poland and to repopulate local rivers (Kolman et al. 2011). These attempts at sturgeon restitution in the Baltic Sea have been followed by genetic monitoring using microsatellite loci to characterize and maintain genetic polymorphism within the established population.

Microsatellite loci are molecular markers commonly used in population genetics, especially in non-model organisms. The usefulness of these markers lies in their assumed neutrality and high level of polymorphism. In conservation genetics, microsatellite loci have been applied for the determination of management units (MUs), and for planning captive breeding programs and population management (DeSalle and Amato 2004). The number of loci needed to obtain reliable results depends upon the type of analysis required and the genetic 
variability of the species under study. For strain identification or relatedness analysis, the use of 15-20 markers to obtain sufficient statistical power is recommended (Blouin et al. 1996; Norris et al. 2000). Individual amplification and length analysis of so many loci is both time-consuming and expensive; therefore, the development and optimization of multiplex assays, enabling simultaneous amplification and analysis of several loci in a single polymerase chain reaction (PCR) assay, is becoming increasingly popular (Zhu et al. 2010; Olafsson et al. 2010; Ciofi et al. 2011). Carefully tested multiplexes allow for the direct comparison of populations studied in different laboratories and for building common databases of genotypes.

Various sets of microsatellite loci have already been employed to study wild and hatchery populations of Atlantic and European sturgeons (Ludwig et al. 2000, 2008; King et al. 2001; Wirgin et al. 2002; Henderson et al. 2004; Williot et al. 2007; Tiedemann et al. 2011; Saarinen et al. 2011; Moyer et al. 2012; Waldman et al. 2013; Wirgin et al. 2012). However, no standardized multiplex set is currently available, despite the utility of such an assay for the sturgeon conservation programs which have recently been started in several countries (Henderson et al. 2004; Gessner et al. 2011; Kirschbaum et al. 2011; Kolman et al. 2011). The aim of the present paper was to develop a microsatellite multiplex assay as a standard, cost-effective genotyping tool for the analysis of Atlantic sturgeon populations. The system was successfully tested on several wild and broodstock sturgeon populations, and we further show that the same approach could also be used for the analysis of the European sturgeon species.

\section{Materials and methods}

\section{Sampling and DNA extraction}

The material for this study consisted of 255 Atlantic sturgeon specimens from seven wild populations from the St. John, St. Lawrence, Kennebec, Hudson, Savannah, Shark, and Delaware Rivers, and 348 specimens from the broodstock kept in the Kuźniczki and Pieczarki Hatchery Stations in Poland and at the Leibniz Institute of Freshwater Ecology and Inland Fisheries in Germany (Supplementary Table 1). The broodstock population was composed of nine year classes, each being the progeny of artificially spawned wild individuals originating from the St. John River. As the number of spawners caught and used for reproduction was limited (usually around five to eight, annually), the year classes were mostly composed of siblings and half-siblings. Additionally, 12 wild specimens of European sturgeon from the Gironde population were analyzed (Supplementary Table 1). DNA was extracted from fin clips preserved in $70 \% \mathrm{EtOH}$. DNA was isolated using proprietary kits [Sherlock AX Kit, Genomic
Mini (A\&A Biotechnology) or Wizard Kit (Promega)], according to manufacturers' instructions. DNA was eluted with sterile water and stored at $-20^{\circ} \mathrm{C}$.

Microsatellite selection and multiplex PCR optimization

Up to 2009, 38 microsatellite loci had been described from Atlantic sturgeon (May et al. 1997; King et al. 2001; Henderson-Arzapalo and King 2002). Of these, we chose 17 loci which had simple, long repeat motifs and which showed the highest polymorphism. These were assigned to four multiplex reactions based on their allele lengths (Supplementary Fig. 1). Before including different loci in the multiplex assays, their potential for primer dimer or hairpin formation was tested in silico, using FastPCR v.3.8.41 with default parameters (Kalendar et al. 2009). To avoid non-specific amplification, the forward primers for AoxD170 and $L s$-62 were modified (Supplementary Table 2). The primer concentration was adjusted experimentally to give similar amounts of PCR products which were evaluated on the chromatogram reads. The final amplification reaction volume of $10 \mu \mathrm{l}$ contained 50-200 ng of DNA, 1× MasterMix (Qiagen Multiplex Kit), and an appropriate concentration of primers, of which the $5^{\prime}$ end of each forward primer was fluorescently labeled (Supplementary Table 2). The PCR conditions were as follows: initial denaturation of $15 \mathrm{~min}$ at $95{ }^{\circ} \mathrm{C}, 35$ cycles of $30 \mathrm{~s}$ at $94{ }^{\circ} \mathrm{C}, 30 \mathrm{~s}$ at $63{ }^{\circ} \mathrm{C}$ (mixes 1 and 2 ) or $61{ }^{\circ} \mathrm{C}$ (mixes 3 and 4 ), $30 \mathrm{~s}$ at $72{ }^{\circ} \mathrm{C}$, and a final elongation of $30 \mathrm{~min}$ at $60^{\circ} \mathrm{C}$. Mixes were loaded onto two autosequencer panels $(1+2$ and $3+4)$. The length reading of PCR products was performed commercially (Oligo.pl, IBB, Warsaw, Poland) on ABI PRISM 377 and 310 automated sequencers with ROX 500 size standard (Applied Biosystems).

Data analysis

Peak Scanner v.1.0 software (Applied Biosystems) was used to bin, score, and output the microsatellite data. MicroChecker v.2.2.3 (Van Oosterhout et al. 2004) was applied to test for errors due to stuttering, null alleles $\left(\mathrm{A}_{\mathrm{N}}\right)$, and large allele dropouts. These analyses were performed for the whole dataset and each of the five most numerous wild populations, using 1,000 randomizations and $95 \%$ confidence interval (CI). The Brookfield 1 (Brookfield 1996) equation was used for null allele frequency estimation. The number of alleles per locus $\left(\mathrm{N}_{\mathrm{A}}\right)$ and probability of identity (PI and PIsibs) were calculated using GenAlEx v.6.5 software (Paekal and Smouse 2001), while GENEPOP v.4.0.10 (Raymond and Rousset 1995) was used to calculate the mean null allele frequency $\left(\mathrm{A}_{\mathrm{N}}\right)$ using maximum likelihood based on the expectationmaximization (EM) algorithm. Observed heterozygosity $\left(\mathrm{H}_{\mathrm{O}}\right)$, expected heterozygosity $\left(\mathrm{H}_{\mathrm{E}}\right)$, and linkage disequilibrium between pairs of loci using 16,000 permutations were 
estimated with Arlequin v.3.5.1.2 (Excoffier and Lischer 2010). Linkage analysis was conducted for the five wild populations of sturgeons (excluding Savannah and Delaware, as their population sizes were considered too small). The average non-exclusion probabilities for parentage assignment (NE-1P, NE-2P, and NE-PP) and the polymorphic information Content (PIC) of the studied loci were calculated separately for the wild and hatchery populations using Cervus v.3.0 (Kalinowski et al. 2007).

\section{Results and discussion}

Multiplex establishment

The multiplex assay for 17 microsatellite loci was tested on a sample of 603 Atlantic sturgeons from both wild and hatchery populations (Tables 1 and 2). Using FastPCR, only the primers for loci AoxD161 and AoxD297 (mix 1) forward primer for locus $L s-68$ (mix 4) could form dimers. However, the amplified products were, nevertheless, clearly distinguishable and easy to score. The obtained allele ranges for each locus of the 603 individuals belonging to the main distribution area of Atlantic sturgeon were non-overlapping (Supplementary Fig. 1). The total successful amplification rate of particular loci varied from 96.5 to $100 \%$, with the exception of locus $L s-62(85.7 \%)$
Table 2 Genetic diversity of the two hatchery populations (a single year class and nine year classes) and of the seven wild populations from North American rivers of Atlantic sturgeon. $\mathrm{N}$-number of individuals tested; $\mathrm{N}_{\mathrm{A}}$-number of alleles; $\mathrm{H}_{\mathrm{O}}$ - observed heterozygosity; $\mathrm{H}_{\mathrm{E}}$ - expected heterozygosity; PIC - polymorphic information content; NE-1P, NE-2P, and NE-PP - average non-exclusion probabilities for the first and second parent and for the parent pair, respectively, calculated for samples of increasing genetic diversity; PI and PIsibs - probability of identity of unrelated and sibling individuals

\begin{tabular}{llll}
\hline & $\begin{array}{l}\text { Hatchery } \\
(\text { single year class })\end{array}$ & $\begin{array}{l}\text { Hatchery } \\
(9 \text { year classes })\end{array}$ & Wild populations \\
\hline $\mathrm{N}$ & 127 & 348 & 254 \\
$\mathrm{~N}_{\mathrm{A}}$ & 3.6 & 9.0 & 14.8 \\
$\mathrm{H}_{\mathrm{O}}$ & 0.71 & 0.61 & 0.60 \\
$\mathrm{H}_{\mathrm{E}}$ & 0.55 & 0.60 & 0.68 \\
$\mathrm{PIC}$ & 0.46 & 0.56 & 0.66 \\
$\mathrm{NE}-1 \mathrm{P}$ & 0.04 & 0.005 & 0.0001 \\
$\mathrm{NE}-2 \mathrm{P}$ & 0.002 & $9.00 \times 10^{-5}$ & $5.00 \times 10^{-7}$ \\
$\mathrm{NE}-\mathrm{PP}$ & $5.00 \times 10^{-5}$ & $1.00 \times 10^{-7}$ & $1.35 \times 10^{-11}$ \\
$\mathrm{PI}$ & $5.82 \times 10^{-10}$ & $3.48 \times 10^{-13}$ & $6.02 \times 10^{-18}$ \\
$\mathrm{PIsibs}$ & $8.00 \times 10^{-5}$ & $1.00 \times 10^{-5}$ & $1.20 \times 10^{-6}$ \\
\hline
\end{tabular}

(Table 1). We subsequently decided to exclude this locus from the multiplex assay, as the low amplification yields were most probably caused by the presence of null alleles and stuttering, as suggested by the results obtained with the Micro-Checker software.
Table 1 Allele size ranges obtained for Atlantic and European sturgeons and gene diversity indices calculated only for Atlantic sturgeons $(N=603$ individuals). $\mathrm{N}_{\mathrm{A}}$-number of alleles; $\mathrm{H}_{\mathrm{O}}$ - observed heterozygosity;
$\mathrm{H}_{\mathrm{E}}$ - expected heterozygosity; $\mathrm{PIC}$ - polymorphic information content; $\mathrm{A}_{\mathrm{n}}$-null allele frequency calculated with GENEPOP and Micro-Checker

\begin{tabular}{|c|c|c|c|c|c|c|c|c|c|}
\hline Locus & $\begin{array}{l}\text { Size range of } \\
\text { A. oxyrinchus }\end{array}$ & $\begin{array}{l}\text { Size range } \\
\text { of } A \text {. sturio }\end{array}$ & $\mathrm{N}_{\mathrm{A}}$ & $\begin{array}{l}\text { Total percentage } \\
\text { of amplifications }\end{array}$ & $\mathrm{H}_{\mathrm{O}}$ total & $\mathrm{H}_{\mathrm{E}}$ total & PIC total & $\mathrm{A}_{\mathrm{n}}$ GENEPOP & $\mathrm{A}_{\mathrm{n}}$ Micro-Checker \\
\hline Aox $\mathrm{C} 45$ & $108-124$ & $112-136$ & 3 & 100 & 0.18 & 0.18 & 0.17 & 0 & 0 \\
\hline AoxD170 & $134-166$ & $158-190$ & 9 & 98.8 & 0.82 & 0.82 & 0.79 & 0.01 & 0 \\
\hline AoxD234 & $195-331$ & $199-211$ & 31 & 98.0 & 0.87 & 0.90 & 0.89 & 0.05 & 0.01 \\
\hline Aox 45 & $109-169$ & $103-145$ & 19 & 99.7 & 0.75 & 0.74 & 0.71 & 0.01 & -0.01 \\
\hline AoxD54 & $174-230$ & $182-194$ & 11 & 99.7 & 0.44 & 0.55 & 0.53 & 0.06 & 0.07 \\
\hline AoxD188 & $262-354$ & $242-250$ & 19 & 98.8 & 0.60 & 0.59 & 0.57 & 0.02 & -0.01 \\
\hline AoxD161 & $126-158$ & $162-170$ & 9 & 99.8 & 0.71 & 0.74 & 0.69 & 0.03 & 0.02 \\
\hline AoxD297 & $185-353$ & $169-173$ & 36 & 97.0 & 0.64 & 0.82 & 0.80 & 0.10 & 0.10 \\
\hline$L s-68$ & $120-172$ & 144 & 11 & 98.7 & 0.64 & 0.77 & 0.73 & 0.08 & 0.07 \\
\hline AoxD241 & $180-272$ & $148-184$ & 24 & 99.5 & 0.89 & 0.90 & 0.89 & 0 & 0 \\
\hline AoxC55 & $114-130$ & $118-142$ & 5 & 100 & 0.23 & 0.23 & 0.21 & 0 & 0 \\
\hline Aox $\mathrm{C} 27$ & $150-174$ & $150-166$ & 6 & 100 & 0.55 & 0.51 & 0.40 & 0.02 & -0.03 \\
\hline AoxD64 & $197-281$ & 221 & 15 & 98.5 & 0.77 & 0.85 & 0.83 & 0.09 & 0.04 \\
\hline AoxD186 & $283-327$ & 287 & 20 & 96.5 & 0.64 & 0.77 & 0.73 & 0.06 & 0.07 \\
\hline AoxD242 & $163-215$ & $243-315$ & 14 & 99.5 & 0.65 & 0.75 & 0.72 & 0.05 & 0.05 \\
\hline AoxC30 & $269-341$ & 257 & 10 & 99.3 & 0.27 & 0.26 & 0.24 & 0 & -0.01 \\
\hline Mean & - & - & 15.2 & 99.0 & 0.60 & 0.65 & 0.62 & - & - \\
\hline$L s$-62 (excluded) & $71-83$ & $75-87$ & 4 & 85.7 & 0.27 & 0.37 & 0.33 & 0.09 & 0.07 \\
\hline
\end{tabular}


Linkage disequilibrium and null allele frequency estimation

Independently performed linkage analysis has shown that the microsatellite loci included into the multiplex assay are not linked with each other, as neither of the pair of loci was repeatedly significantly linked across all five examined populations. No evidence of large allele dropouts or false alleles was obtained. However, four loci (AoxD54, AoxD297, Ls-68, AoxD186) could exhibit stuttering according to MicroChecker and four loci (AoxD186, AoxD54, AoxD297, Ls-68) could be biased with null allele presence, with the frequency exceeding 0.05 for both tests (Table 1). Analyses of the five wild populations separately have shown (according to the Brookfield 1 method) that only some of the loci could exhibit null alleles (data not shown), but not across all of the studied populations (AoxD186 in none, AoxD54 in one, $L s$-68 in two, and AoxD297 in three populations). The highest $\mathrm{A}_{\mathrm{n}}$ values, reaching 0.10, were obtained for AoxD297. However, as the most polymorphic locus, we consider this to be a valuable member of the multiplex assay. The $A_{n}$ values obtained for other loci were usually close or equal to zero. The occurrence of null alleles in a large sample of individuals representing populations from a very broad geographic range is not a surprise considering the high mutation rates of the microsatellite loci ranging, on average, $5 \times 10^{-4}$ per generation (Schlötterer 2004).

Polymorphism and assignment power of the selected markers

The results presented in Table 1 indicate that all the loci included in the multiplex assay were polymorphic. The number of alleles varied from three (AoxC45) to 36 (AoxD297), and averaged 15.2 per locus, making this multiplex assay a valuable tool for population analysis. Observed heterozygosity also varied strongly between the loci, often departing from the mean value of 0.60 . The PIC values, which depend on both allele frequency and heterozygosity, varied between 0.17 for AoxC45 and 0.89 for AoxD234 and AoxD241. As expected, all indices of genetic polymorphism were lower for the hatchery population than for wild fish, presumably as a result of using a limited number of spawners for reproduction (Table 2). Despite that, the PI values were still sufficiently high to distinguish even highly related individuals. The same was true also for the paternity analysis, where non-exclusion probabilities had very low values, minimizing the probability of errors of false parent identification. These results demonstrate that the designed multiplex assay could serve well for both stock identification and kinship analysis. Even when a single year class, containing the progeny of one female and two males, was analyzed (Table 2), the PI and non-exclusion probabilities were sufficiently low to assure proper individual and parental identification.
Cross-species amplification in A. sturio

The multiplex assay was also tested on 12 individuals of European sturgeon (A. sturio). For five loci, the optimal annealing temperature had to be lowered to $58{ }^{\circ} \mathrm{C}$ (AoxD188, Aox $2756{ }^{\circ} \mathrm{C}$ (AoxC45), and $54{ }^{\circ} \mathrm{C}$ (AoxD242) for successful amplification, but even at these temperatures, the amplification of Aox 45 and AoxD242 remained problematic. Four loci seemed to be monomorphic (Table 1), although analysis of a larger sample may reveal more alleles for these loci, as shown previously for $L s-68$ (Chassaing et al. 2011b). The low variability of European sturgeon is not surprising, because only a single, very small, and probably bottlenecked population of species remains (Williot et al. 2007). For five loci (AoxD161, AoxD188, AoxD297, AoxD242, and Aox C30), the allele range sizes of Atlantic and European sturgeons did not overlap. These loci together could serve as a powerful tool for species or hybrid identification. Chassaing et al. (2011b) has already suggested the use of AoxD161 as a diagnostic marker distinguishing Atlantic and European sturgeons. If the multiplex assay described here is used to analyze European sturgeon populations, we suggest the use of a fourth fluorescent dye to label microsatellite loci AoxD161, AoxD242, and $L s-68$, as the allele size ranges of these loci overlap with those of some others.

\section{Conclusions}

The described multiplex assay, covering 16 microsatellite loci, amplified in four polymerase chain reaction (PCR) assays and loaded on the ABI DNA analyzer in two separate panels, can be successfully applied in the genetic analysis of populations and relatedness assignment in captive breeding programs of Atlantic sturgeon. The optimized microsatellite set may also be used for European sturgeon; however, for optimal results in this case, we recommend the addition of loci designed specifically for this species (Tiedemann et al. 2011). Five loci were identified which can be used for the detection of introgression between the two sturgeon species. The designed multiplex assay has already been applied in practice and will be used for creating a pedigree book and optimal cross design for the broodstock of Atlantic sturgeon during its reintroduction in Poland (Stankovic 2011).

Acknowledgments We thank Patrick Berrebi, Ryszard Kolman, Jörn Gessner, Marek Raczkowski, Mirosław Szczepkowski, Arne Ludwig, Bernie May, Timothy King, Barb Lubinski, Eric Rochard, Isaac Wirgin, Jason Bartlett, and Gail Wipplehauser for providing fish samples. We are very grateful to Martyna Molak for the help with editing the manuscript and to Philip Harris for the English proofreading and corrections. We thank Mateusz Baca, Kinga Czarnogórska, Magdalena Gonciarz, and Katarzyna Pajak for their laboratory assistance. The study was carried out with the support of the project financing agreements POIG.02.02.00- 
14-024/08-00 through grants ZPB/62/72380/IT2/10 and NR12012910 (NCBiR) and with use of CePT infrastructure financed by the EU. The authors declare that all experiments presented in this study comply with the current laws of Poland.

Contributors H.P. and D.P. performed the experiments and analyzed the data. K.Z. performed the experiments. H.P., D.P., P.W., and A.S. wrote the manuscript. P.W. and A.S. designed and directed this project.

Open Access This article is distributed under the terms of the Creative Commons Attribution License which permits any use, distribution, and reproduction in any medium, provided the original author(s) and the source are credited.

\section{References}

Blouin MS, Parsons M, Lacaille V, Lotz S (1996) Use of microsatellite loci to classify individuals by relatedness. Mol Ecol 5:393-401

Brookfield JFY (1996) A simple new method for estimating null allele frequency from heterozygote deficiency. Mol Ecol 5:453-455

Chassaing O, Desse-Berset N, Duffraisse M, Piquès G, Hänni C, Berrebi P (2011a) Palaeogeographic patterns of A. sturio. In: Williot P, Rochard E, Desse-Berset N, Kirschbaum F, Gessner J (eds) Biology and conservation of the European sturgeon Acipenser sturio L. 1758. Springer, Berlin, pp 117-129. ISBN 978-3-642-20610-8

Chassaing O, Hänni C, Berrebi P (2011b) Distinguishing species of European sturgeons Acipenser spp. using microsatellite allele sequences. J Fish Biol 78:208-226

Chassaing O, Desse-Berset N, Duffraisse M, Hughes S, Hänni C, Berrebi P (2013) Palaeogenetics of western French sturgeons spotlights the relationships between Acipenser sturio and Acipenser oxyrinchus. J Biogeogr 40(2):382-393

Ciofi C, Tzika AC, Natali C, Watts PC, Sulandari S, Zein MSA, Milinkovitch MC (2011) Development of a multiplex PCR assay for fine-scale population genetic analysis of the Komodo monitor Varanus komodoensis based on 18 polymorphic microsatellite loci. Mol Ecol Resour 11:550-556

DeSalle R, Amato G (2004) The expansion of conservation genetics. Nat Rev Genet 5:702-712

Excoffier L, Lischer HEL (2010) Arlequin suite ver 3.5: a new series of programs to perform population genetics analyses under Linux and Windows. Mol Ecol Resour 10:564-567

Gessner J, Tautenhahn M, Spratte S, Arndt G-M, von Nordheim H (2011) Development of a German Action Plan for the restoration of the European sturgeon Acipenser sturio L. - implementing international commitments on a national scale. J Appl Icthyol 27:192-198

Henderson AP, Spidle AP, King TL (2004) Genetic diversity, kinship analysis, and broodstock management of captive Atlantic sturgeon for population restoration. In: Propagated Fish in Resource Management, American Fisheries Society Symposium, 44, pp 621-633

Henderson-Arzapalo A, King TL (2002) Novel microsatellite markers for Atlantic sturgeon (Acipenser oxyrinchus) population delineation and broodstock management. Mol Ecol Notes 2:437-439

Kalendar R, Lee D, Schulman AH (2009) FastPCR software for PCR primer and probe design and repeat search. Gene Genome Genom 3: 1-14. http://primerdigital.com/fastpcr.html

Kalinowski ST, Taper ML, Marshall TC (2007) Revising how the computer program CERVUS accommodates genotyping error increases success in paternity assignment. Mol Ecol 16:1099-1106. doi:10. $1111 / j .1365-294 x .2007 .03089 . x$

King TL, Lubinski BA, Spidle AP (2001) Microsatellite DNA variation in Atlantic sturgeon (Acipenser oxyrinchus oxyrinchus) and crossspecies amplification in the Acipenseridae. Conserv Genet 2:103-119
Kirschbaum F, Williot P, Fredrich F, Tiedemann R, Gessner J (2011) Restoration of the European Sturgeon Acipenser sturio in Germany. In: Williot P, Rochard E, Desse-Berset N, Kirschbaum F, Gessner J (eds) Biology and conservation of the European sturgeon Acipenser sturio L. 1758. Springer, Berlin, pp 309-333

Kolman R, Kapusta A, Duda A, Wiszniewski G (2011) Review of the current status of the Atlantic sturgeon Acipenser oxyrinchus oxyrinchus Mitchill 1815, in Poland: principles, previous experience, and results. J Appl Icthyol 27:186-191

Lassalle G, Béguer M, Rochard E (2011) An overview on geographical distribution from past descriptions. In: Williot P, Rochard E, DesseBerset N, Kirschbaum F, Gessner J (eds) Biology and conservation of the European sturgeon Acipenser sturio L. 1758. Springer, New York, pp 81-90

Ludwig A (2006) A Sturgeon view on conservation genetics. Eur J Wildl Res 52:3-8

Ludwig AN, Jenneckens I, Debus L, Ludwig A, Becker J, Kirschbaum F (2000) Genetic analyses of archival specimens of the Atlantic sturgeon Acipenser sturio L., 1758. Bol Inst Esp Oceanogr 16:181-190

Ludwig A, Debus L, Lieckfeldt D, Wirgin I, Benecke N, Jenneckens I, Williot P, Waldman JR, Pitra C (2002) When the American sea sturgeon swam east. Nature 419:447-448

Ludwig A, Arndt U, Lippold S, Benecke N, Debus L, King TL, Matsumura S (2008) Tracing the first steps of American sturgeon pioneers in Europe. BMC Evol Biol 8:221

Ludwig A, Makowiecki D, Benecke N (2009) Further evidence of transAtlantic colonization of Western Europe by American Atlantic sturgeons. Archeofauna 18:185-192

May B, Krueger CC, Kincaid KL (1997) Genetic variation at microsatellite loci in sturgeon: primer sequence homology in Acipenser and Scaphirhynchus. Can J Fish Aquat Sci 54:1542-1547

Moyer GR, Sweka JA, Peterson DL (2012) Past and present processes influencing genetic diversity and effective population size in a natural population of Atlantic sturgeon. Trans Am Fish Soc 141:56-67

Norris AT, Bradley DG, Cunningham EP (2000) Parentage and relatedness determination in farmed Atlantic salmon (Salmo salar) using microsatellite markers. Aquaculture 182:73-83

Olafsson K, Hjorleifsdottir S, Pampoulie C, Hreggvidsson GO, Gudjonsson S (2010) Novel set of multiplex assays (SalPrint15) for efficient analysis of 15 microsatellite loci of contemporary samples of the Atlantic salmon (Salmo salar). Mol Ecol Resour 10:533-537

Paaver T (1999) Historic and recent records of native and exotic sturgeon species in Estonia. J Appl Icthyol 15:129-132

Paekal R, Smouse PE (2001) GenAlEx V5: genetic analysis in Excel. Population genetic software for teaching and research. http:// biology.anu.edu.au/GenAlEx/

Pikitch EK, Doukakis P, Lauck L, Chakrabarty P, Erickson DL (2005) Status, trends and management of sturgeon and paddlefish fisheries. Fish Fish 6:233-265

Raymond M, Rousset F (1995) Genepop (version 1.2): population genetics software for exact tests and ecumenicism. J Hered 86:248249

Saarinen EV, Flowers JH, Pine WE, Parauka F, Austin JD (2011) Molecular kin estimation from eggs in the threatened Gulf sturgeon. J Appl Ichthyol 27(2):492-495

Schlötterer C (2004) The evolution of molecular markers - just a matter of fashion? Nat Rev Genet 5:63-69

Stankovic A (2011) The past and future of sturgeons in Poland: the genetic approach. In: Williot P, Rochard E, Desse-Berset N, Kirschbaum F, Gessner J (eds) Biology and conservation of the European sturgeon Acipenser sturio L. 1758. Springer, Berlin, pp $561-572$

Tiedemann R, Schneider A, Williot P, Kirschbaum F (2011) Genetic variability of cultured European sturgeon Acipenser sturio. In: Williot P, Rochard E, Desse-Berset N, Kirschbaum F, Gessner J 
(eds) Biology and Conservation of the European sturgeon Acipenser sturio L. 1758. Springer, Berlin, pp 455-464

Van Oosterhout C, Hutchinson WF, Wills DPM, Shipley P (2004) MICRO-CHECKER: software for identifying and correcting genotyping errors in microsatellite data. Mol Ecol Notes 4:535-538

Vecsei P (2005) Gastronome 101: how capitalism killed the sturgeons. Environ Biol Fish 73:111-116

Waldman JR, Wirgin II (1998) Status and restoration options for Atlantic sturgeon in North America. Conserv Biol 12:631-638

Waldman JR, King T, Savoy T, Maceda L, Grunwald C, Wirgin I (2013) Stock origins of subadult and adult Atlantic sturgeon, Acipenser oxyrinchus, in a non-natal estuary, Long Island Sound. Estuar Coasts 36:257-267. doi:10.1007/s12237-012-9573-0

Williot P, Rouault T, Pelard M, Mercier D, Lepage M, Davail-Cluisset B, Kirschbaum F, Ludwig A (2007) Building a broodstock of the critically endangered sturgeon Acipenser sturio: problems and observations associated with the adaptation of wild-caught fish to hatchery conditions. Cybium 31:3-11

Wirgin I, Waldman JR, Stabile J, Lubinski B, King T (2002) Comparison of mitochondrial DNA control region sequence and microsatellite DNA analyses in estimating population structure and gene flow rates in Atlantic sturgeon Acipenser oxyrinchus. J Appl Ichthyol 18:313319

Wirgin I, Maceda L, Waldman JR, Wehrell S, Dadswell D, King T (2012) Stock origin of migratory Atlantic Sturgeon in Minas Basin, Inner Bay of Fundy, Canada, determined by microsatellite and mitochondrial DNA analyses. Trans Am Fish Soc 141: 1389-1398

Zhu ZY, Wang CM, Lo LC, Lin G, Feng F, Tan J, Chou R, Lim HS, Orban L, Yue GH (2010) A standard panel of microsatellites for Asian seabass (Lates calcarifer). Anim Genet 41:208-212 